Article

\title{
Evolution of Edges and Porosity of Urban Blue Spaces: A Case Study of Gdańsk
}

\author{
Justyna Breś and Karolina A. Krośnicka * \\ Department of Urban Design and Regional Planning, Faculty of Architecture, Gdańsk University of Technology, Poland; \\ E-Mails: justyna.bres@pg.edu.pl (J.B.), karolina.krosnicka@pg.edu.pl (K.A.K.) \\ * Corresponding author
}

Submitted: 30 January 2021 | Accepted: 1 May 2021 | Published: 27 July 2021

\begin{abstract}
Current waterfront studies focus mainly on a land-based perspective, failing to include the water side. Water is, however, not just a resource for port and industrial purposes and an edge to the waterfront; it is also a feature of the waterfront and the complex relation between water and city. Thus, the article suggests that water-land edges need to be re-contextualised, taking into consideration also their shape, functionality, and evolution over time. This article therefore introduces the concept of urban blue spaces, that is, spaces that include at least one land-water edge, such as a shoreline or river edge. The types and character of these edges define the porosity of urban blue spaces: Spaces with easy connections, such as boulevards or parks, are highly porous, while fenced areas have low porosity. The research first analyses the existing literature on the spatial and functional characteristics of the land-water edge in port cities, and explores existing typologies of urban blue spaces. The results of this investigation are used to examine the most iconic urban blue space of Gdańsk, the Motława river, over the last 1000 years. The case study shows that the porosity of the Gdańsk urban blue space has been increasing over time, in line with its spatial and functional development from an undeveloped riverbank to a 'gated' port and industry area, to urban living spaces today. The article thus presents the whole breadth of urban blue spaces through the case study of the Motława river urban blue space. The spatial evolution of the urban blue space is depicted through the transformation of its land-water edge-from a natural sloping edge to the dominance of vertical edged structures or ones overhanging the surface of the water, to the emergence of spatially 'blurred' sloping, slanted, terraced, and floating structures, partially independent of the riverbank. The transformation of the structure of the Motława urban blue space edges increased its complexity over time, from a single-edge structure to a double and multiple-edged one.
\end{abstract}

\section{Keywords}

Gdańsk; land-water edge; port city; urban blue space; waterfront

\section{Issue}

This article is part of the issue "Planning for Porosity: Exploring Port City Development through the Lens of Boundaries and Flows" edited by Carola Hein (Delft University of Technology, The Netherlands).

(C) 2021 by the authors; licensee Cogitatio (Lisbon, Portugal). This article is licensed under a Creative Commons Attribution 4.0 International License (CC BY).

\section{Introduction}

Water has been present within public spaces since ancient times. However, aquatic space became the subject of spatial planning only at the end of the 20th century (Zaucha, 2009). In the second half of the 20th century research has given thorough attention to the influence of water on the development of urban public spaces and notably the waterfront (Breen \& Rigby, 1996; Bruttomesso, 1993; Hall, 1993; Hoyle, 1989; Meyer, 2001; Vallega, 2001). The aquatic space, however, has not been recognised as a spatial resource that should be planned along with the adjacent land, as the concept of waterfronts refers more to the land area, rarely including the body of water. Currently, we observe the progressive occupation of water spaces in cities, 
by functions that have so far been the domain of land areas (Couling \& Hein, 2020; Hein, 2016; Jerzak et al., 2019). In the 21st century, politicians, planners, and scholars have rediscovered water areas in cities as a spatial resource and a platform for public activity. The concept of urban blue space has taken shape in the academic field in the last decade (Brand, 2007; Breś, 2018; Gledhill \& James, 2008; Haeffner et al., 2017; Taufen-Wessells, 2014; Völker et al., 2016). Due to the intensification of the use of aquatic spaces, the level of their complexity as well as the number of spatial conflicts between their stakeholders is rising. Thus, water should be thoroughly planned together with the surrounding land to increase the multifunctionality and efficiency of both environments.

The authors use the case of the historic city centre of Gdańsk, Poland, to illustrate the theoretical considerations on the function and shape of blue urbanised spaces. This iconic public space of Gdańsk, stretching along the Motława river, was not built from a single projection. It has been shaped over hundreds of years as the main port of Gdańsk. It was transformed according to the rhythm of technological leaps and changes in the organisation and lifestyle of the city's inhabitants. These changes, recorded in the physical space of the port and the city, and in the archaeological evidence; drawings and cartographic materials illustrate the dynamics of the functional and spatial transformations of this main water space of the city in subsequent historical epochs. This article explores the urban blue space of Gdańsk in terms of changes in space and time. The observed specific functional life cycle of the area of the Motława river, interrupted from time to time by massive war damage $(1308,1454,1734,1945)$, is reflected in the changes of the waterfront through the following phases: natural landscape with ecological and agricultural functions; landscape of a working waterfront (port and shipyard); a post-port landscape related to commercial and housing functions; and finally an intensely built-up water square, fulfilling cultural functions. A long-term perspective, taking into account the life cycle of urban spaces and its planning, further confirms the need to consider water areas in the spatial planning process.

\section{Spatial Characteristic of Urban Blue Space}

Urban blue space is understood as an area consisting of both water and land and therefore including at least one land-water edge (e. g. shoreline, riverbank), usually separated from the surroundings by at least one physical edge (e.g., line of hills, buildings, wall, forest). A determinant of urban blue space is its tangible and intangible relation with water, which largely influences the character of the space. The boundaries (edges) of urban blue space, defining it as an urban interior, may vary according to topographic conditions, functional layout, and surrounding urban structures. The structure of urban blue spaces edges (or any other urban spaces) is not uniform - it has voids (pores) of a different size, distribution, and character, through which the human flows might pass, allowing them to pass from sea to land and land to sea. The feature of existence of voids within the volume of urban blue space edge the authors call porosity. The more pores the edge contains, the higher its porosity and at the same time the permeability for human flows.

The porosity of urban blue space depends mostly on the type of its edge (Figure 1). The urban blue space edge might be a solid wall, fence, or line of buildings not accessible for people, such as for example a port basin with surroundings quays detached from the surrounding area by industrial buildings. It might take the form of a row of buildings cut by streets, passages, and view openings, for example, a boulevard along the river limited on one side by a row of trees and on the other by building frontages with the views opened to the water. The urban blue space can have an undefined edge, where no physical boundaries detach the urban blue space from the neighbouring area, such as a bathing area covering

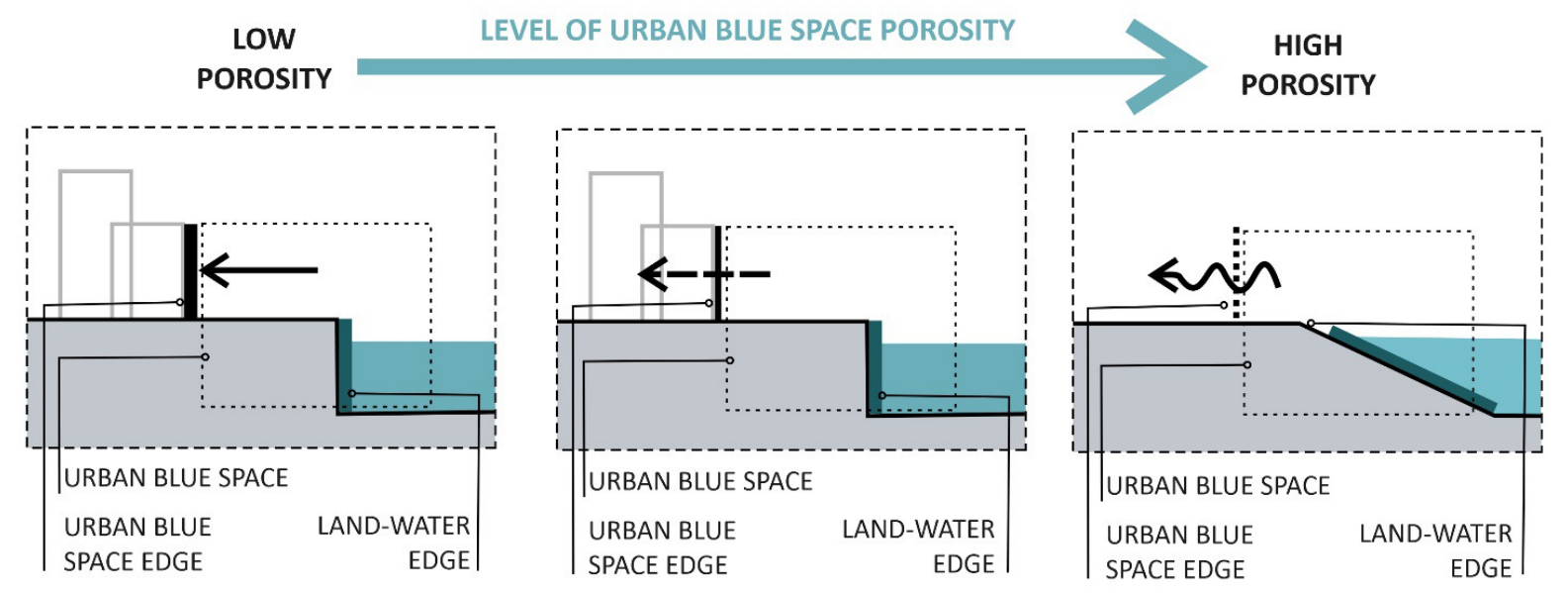

Figure 1. Types of urban blue space edge in terms of their porosity. From left to right, the images show increased accessibility from land to water, and thus increased porosity. 
both the beach and swimming area with no 'solid' edges delimiting the space.

The urban blue space might have one or more spatial edges (Figure 2). It may be limited from the land side by a single edge of buildings, infrastructure, or greenery, while on the other side there can be an uninterrupted view to the open waters or the other bank of the river. The space might be limited from two sides (double edge) and encompass water in the middle, forming a 'water street.' Finally, urban blue space might be surrounded by walls from many sides, taking the form of a 'water square.' The layout of urban blue space may constitute a network of all types mentioned above, creating a complex spatial system. The number of edges and their character determine the level of compactness of the interior of the urban blue space and its landscape porosity.

Water, which changes its function, shape, physical state, and colour, interferes with the adjacent territory and affects the multidimensionality of the water-land relation. The physical embodiment of this relation is the edge between the water and land areas. The edges of urban blue spaces may vary in their spatial layout and their section (Januchta-Szostak, 2011; Prominski et al., 2012). The land-water edge, in terms of its section, might be described as 'fixed' or 'flexible' (Figure 3). A fixed land-water edge does not change its position in time (except for emergencies). It is typical for transport, industrial, and infrastructural functions of urban blue spaces, such as a sheet pile wall in a port. Usually, the fixed edge does not provide users with direct access to the water, only enabling access to the water transportation units moored to the wharf and providing only a view to the water. A flexible edge changes its position in time according to fluctuations of the water level. This kind of edge is characteristic for waterfronts fulfilling residential, recreational, and commercial functions-most often, they appear in parks, and along boulevards and pedestrian streets. This water-land connection provides users with greater contact with the aquatic environment and often direct access to the water. There are various types of flexible edges within urban blue space, such as a sloping edge gently leaning into the water, a slanted edge with a steeper slope, a terraced edge with a multilevel floor, and a floating one, adapting to the changing water level.

A land-water edge might be also characterised by its layout (Burda, 2015; Meyer, 1999; Moughtin, 2003; Niemann \& Pramel, 2017; Yang, 2006). An urban blue space might have a connection with the existing waterline or be separated from it (Figure 4). The first type of land-water edges might have no physical connection to the existing water line and be located further into the aquatic space (an island) or territory (land area having intangible connections with the water). The second type of land-water edge is physically connected to the original shoreline and might run longitudinally, perpendicularly, or independently from it. In the case of a narrow strip of water, the land-water edge might be connecting two water lines with a bridge.

An important factor in the case of the land-water edge is the impact of time, which plays a much greater role in the case of urban blue space than in the case of

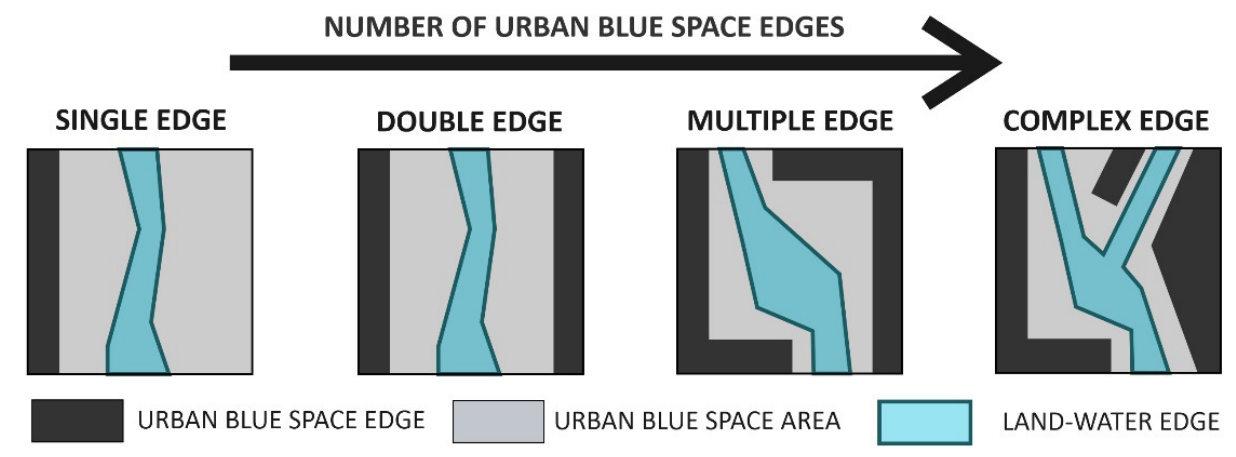

Figure 2. Urban blue space type in terms of number of edges.
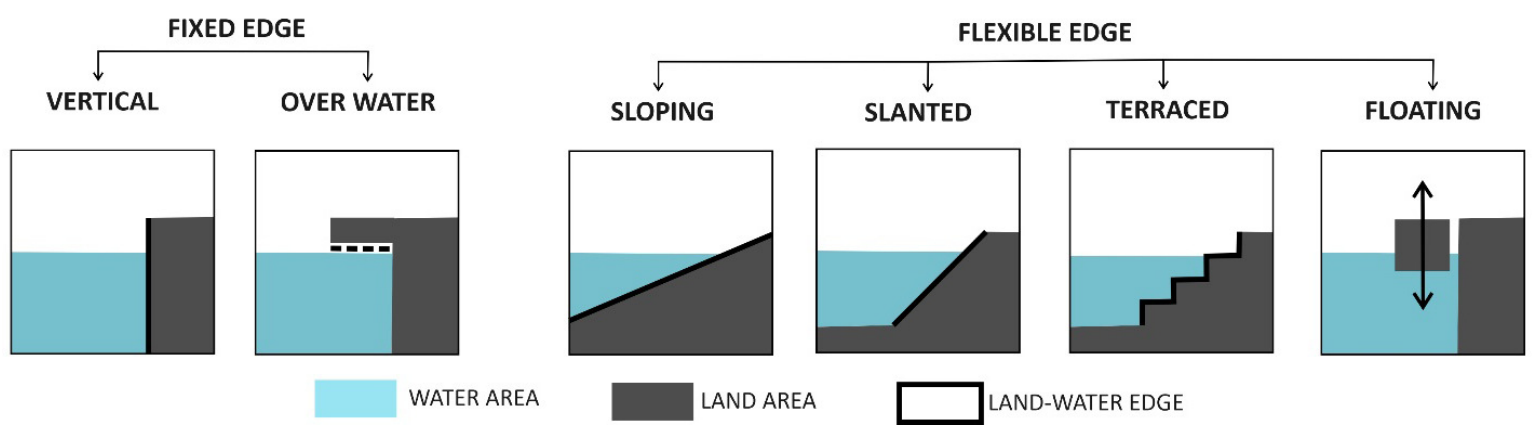

Figure 3. Types of water-land edges according to their relation to the waterline (shore or riverbank). 


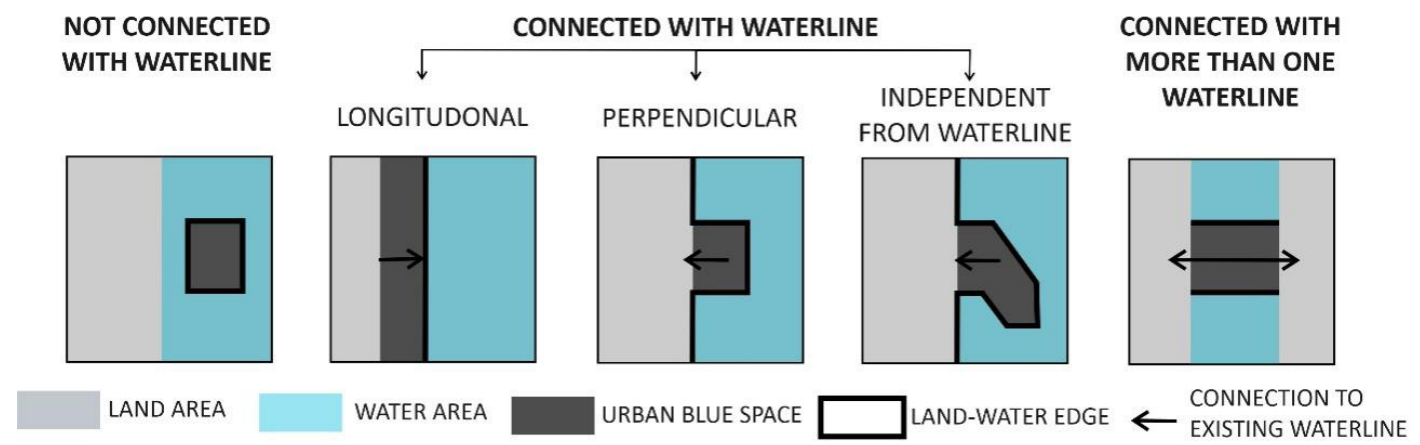

Figure 4. Types of land-water edge spatial layout in terms of the relation between water and land.

land area. Transformation of a land-water edge occurs on various time scales: it might be the matter of occasional changes due to some extraordinary weather conditions affecting the water level, periodic processes such as tides, or hydrological evolution happening over hundreds of years (Schwarzer et al., 2003; Sherman \& Bauer, 1993). The 'mixture' of different temporal and spatial scales require more complex knowledge on the ongoing processes at the edge of the water and land to be obtained while planning the urban blue space (Finkl, 2004). The dynamic character of aquatic space and changes of the land-water edge in time affect the spatial management and functioning of urban blue space, which is essential for development of port cities and may play a number of roles within an urban environment.

\section{Functional Characteristic of Urban Blue Space}

Urban blue space might have various functions: transportation and industry (Couper, 1983; Sorensen \& McCreary, 1990; Vallega, 1992); agriculture and ecological purposes (Gledhill \& James, 2008; Taufen-Wessells, 2014; Völker et al., 2016); and housing, services and commercial (Feiler, 2007; Olthuis \& Keuning, 2010). The compared classifications of waterfront functions largely comprise industrial, transport, residential, and recreational functions. Hoyle (1989) recognised the port function, comprising the industrial as well as derelict post-industrial use, residential, recreational, commercial, cultural, and transport function of the space, which is quite similar to what was introduced later by Hall (1993). Breen and Rigby (1996), apart from such functions as commercial, cultural and educational, recreational, residential, working, and transportation, also distinguished another type of area at the water frontage-the historic waterfront. Vallega (2001), describing the types of uses that have replaced a relocated port or the industrial function through the process of revitalisation, introduces the following types of successor functions: communication (transport), settlement (residential), recreation and tourism, cultural heritage (historical), and research. Meyer (2001) describes types of waterfront areas and divides them into four functional sections: industrial, transport, recreation, and residential. Moughtin (2003), in his research on public space, distinguishes waterfront as a specific type of public space and introduces its following functions: commercial, industrial, transport, leisure, and residential. Januchta-Szostak (2011) presented an exceptional approach, which shows an attempt to understand the area at the edge of the water and land as both land and aquatic space. In her research, she recognised the following functional types of the area at the edge: defensive, land transportation, water transportation, recreational, and economic.

The currently dominant land-based approach on the functional use of waterfront areas is not enough to thoroughly understand the functioning of urban blue space, which comprises elements of the aquatic environment. Therefore, it is also vital to analyse the subject of functioning of the space at the edge of the water and land from the water perspective. Research on the urban use of aquatic space dates back to the late 1980s and has been conducted mainly within the field of marine spatial management or economy related to urban development. Couper (1983) describes economic activity sectors within the aquatic area, including navigation and communications, strategy and defence, research, recreation, and management, as well as activities connected with natural features of the aquatic environment, such as mineral and energy resources, biological resources, waste disposal, and the environment. The functional division delivered by Sorensen and McCreary (1990) comprises coastal uses based on marine economic sectors (recreation development, tourism development, port development, energy development, industrial siting, agriculture, and mariculture development), activities connected with coastal resource exploitation (fisheries, water supply), and functions referring to the protection of the coastal environment (natural area protection systems, and oil and toxic spill contingency planning). Pido and Chua (1992) distinguish the following purposes of coastal environment use: agriculture, fisheries and aquaculture, infrastructure, mining, ports and harbours, industry, tourism, urban development, forestry, and shipping. In turn, Vallega (1992) presents a detailed functional framework, which includes resources (biological, mineral, energy resources), activity sectors (seaports, various kinds of shipping, air transportation), man-made 
structures (underwater infrastructure, defence infrastructure, waterfront structure, recreational infrastructure), and environmental protection (waste disposal, research, archaeology, and environment preservation).

Synthetising the above, three categories, with regard to their environmental impact and therefore the type of landscape, were distinguished: environmental functions, urban living functions, and urban industrial functions (Table 1). The environment-oriented category includes activities such as scientific research on coastal habitats, protection of the cultural and natural environment and pollution prevention, agriculture and mariculture, and exploitation of natural resources such as fauna, flora, and the water itself. Urban living space refers to an inhabited urban environment characterised with more intensive spatial development such as communication space dedicated for individual or public transport, various services including commercial use of space, cultural and educational functions, recreation, greenery, and residential function. The third includes industrial use providing such functions as industry and port activity, technical and hydrotechnical infrastructure, energy production and mining, waste disposal as well as post-industrial brown of grey fields. Among the mentioned urban functions, the ones of public use, such as transport, culture, commerce, and recreation, are of the greatest importance for the city structure.

The transport functions characteristic for such urban blue space are a fairway, ferry terminal, port or yacht marina, or bridge. The main purpose of a fairway is the communication of water vessels. A water transport junction, such as a port or marina, connects collective and individual means of water transport to inland transportation and creates a unique identity of the city. Bridges might come in various forms-from traditional permanent bridges to bascule, swing, or rotational ones. Although their primary function is transport, they often become a city landmark.

An urban blue space connected with the cultural function is a water square or plaza, which performs a representative function for cultural, educational, and recreational activity with the possibility of hosting public events. A water square consists of a basin surrounded by land or a square adjacent to the water. A water boulevard might also play a cultural, representative, or recreational role. It often constitutes an icon of the city. Sometimes, apart from being used for recreational purposes, it serves as a reloading and mooring berth. A boulevard usually provides visual access to the water, sometimes with the possibility for physical contact with the water or access to ships moored to the embankment.

The commercial function is performed by a water market, where the main function is trade and exchange of goods. In the past, port markets played a significant role in port cities, however, in the present times of globalisation, the function of port marketplaces is fading since the trade has moved inland to fish direct sale centres or other service and commercial premises. Fish markets adjacent to the water are currently mainly tourist attractions.

A pier is a unique urban blue space, the main function of which is recreation, sometimes combined with transport. Similarly to the waterfront boulevard, it might become a landmark of the city. It is a public space situated perpendicularly to the coast which stretches towards the water and is surrounded by it from three sides. Recreational blue space might also serve for sports and leisure activities, for example, a beach with a bathing area, surfing, scuba diving spot, or regatta course, where users come into direct physical contact with the water. It can also take the shape of a reservoir or a floating sports facility such as a floating swimming pool or recreational pavilion. A type of urban blue space with a dominant recreational function with significant environmental value may be a park located by or on the water. In this case, urban blue space might be understood as a water surface occasionally traversed by humans or an underwater area rich in flora and fauna constituting a tourist attraction for divers.

As described above, urban blue public spaces can fulfill a large variety of functions, responding different needs of their users. Moreover, the functions of urban blue public spaces have transformed over the centuries. The process of evolution of the form and function of urban blue space takes place in many developing port cities. An interesting example, which depicts

Table 1. Urban blue space functional typology.

\begin{tabular}{ccc}
\hline & Urban blue space functions & $\begin{array}{c}\text { Urban environment } \\
\text { Industry } \\
\text { Infrastructure }\end{array}$ \\
\hline Natural environment & $\begin{array}{c}\text { Urban environment } \\
\text { Living }\end{array}$ & Defence \\
Research & Transport & Port \\
Environmental protection & Infrastructure & Industrial \\
Agriculture and mariculture & Residential & Transport \\
Biological resource & Cultural, educational & Infrastructure \\
& Commercial & Energy production \\
& Recreational & Waste disposal \\
\hline
\end{tabular}


the transformation of space at the edge of water from medieval times until the present, is the case of Gdańsk.

\section{Gdańsk Case Study: From Medieval Port to Water Plaza and Water Streets}

The evolution of the historic port area in the city of Gdańsk is presented in a simplified form in Figure 5. In order to understand the evolution of the urban blue space of the Motława river, it is necessary to describe the successive phases of its thousand-year development reflecting the changes in this area in terms of: porosity of the urban blue space edges; number of edges of the urban blue space; types of land-water edges according to their relation to the waterline; and types of landwater edges according to their spatial layout. The distinguished phases (1050-1308, 1308-1454, 1454-1560, 1560-1630, 1630-1820, 1820-1945, 1945-2010, 2010- present) are briefly characterised below in relation to the historical events which have defined and shaped their spatial character (Figure 6).

The seaport along the Motława River started to emerge in the early Middle Ages at the southern foot of the fortified Slavic stronghold (castellum) located on the island, near today's Grodzka street (Śliwiński, 2016, p. 163; Zbierski, 1964, pp. 204-205). The stronghold port, where small-draft boats were handled, was formed as an oblong wooden embankment, probably freely accessible to the inhabitants, but also serving commercial functions (Cieślak et al., 1978, p. 92). The arrival of Lübeck merchants in Gdańsk around the mid-12th century resulted in the establishment of a merchant's kontor (palatium), which was a fortified trade settlement with its port (Cieślak et al., 1978, p. 219; Zarębska, 1998, p. 18). In connection with the widespread use of Hanseatic cogs, the depth demands of the port increased and a group

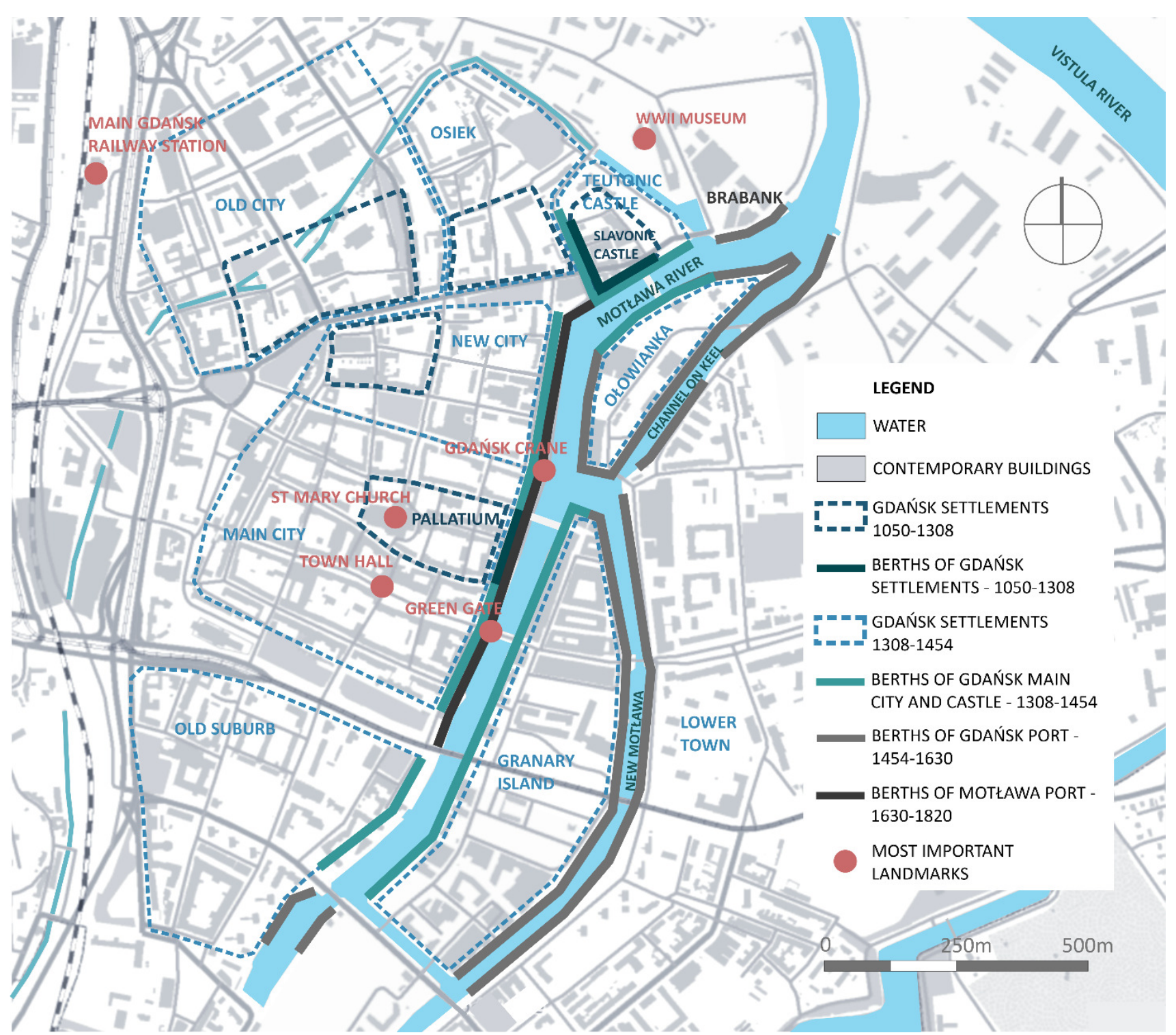

Figure 5. Map of the historic port of Gdańsk on Motława river presenting the phases of the port's development and location of medieval 'cities' and districts. Source: Own elaboration based on Interaktywny Plan Gdańska (n.d.). 
of piers was built (Zbierski, 1964, p. 220). Piers in the form of wooden platforms soon also appeared at the Slavonic stronghold port. Most likely, these platforms did not allow access by outsiders.

During the years 1050-1308, within the Motława blue space there were two independently functioning centres (palatium and Slavonic strongholds), both with single-edged spatial land-sea structures. In each of the centres, the city was separated from the port and water area by a solid structure (a wall or a rampart). In both cases, the port infrastructure was placed over water (piers; Figure 6a).

In 1308, the Slavic stronghold and the Lübeck cantor were destroyed and the activity of their ports was suspended for some time (Śliwiński, 2016, p. 201). However, around the year 1340, in the place of the former stronghold, a Teutonic castle was built (Cieślak et al., 1978 , p. 345). In the area of the former palatium (approximately the area between Świętego Ducha and Ogarna streets), the new city, the so-called Main Town, was founded (Cieślak et al., 1978, p. 358). The number of wooden piers increased then, as they were built along the frontline of the city walls. Access to the piers from the city was possible only via so-called water gates (Figure 6b).

With the creation of the so-called New Town (Cieślak et al., 1978, p. 366), new water gates and port piers were built between Szeroka street and the Fish Market (Zarębska, 1998, p. 22). A reloading crane was built at the gate of Szeroka street in 1379, which is still a symbol of this place. The Brabank workshops and Lastadia shipyard and the Old Suburb district were erected around 1360 , completing the urban layout of the left bank of the Motława River.

The increase in the port's turnover made new storage facilities and mooring berths necessary. The Cog bridge was built (today's Green bridge), heading to the right bank of the Motława River, being at that time a marshy area of meadows with oxbow lakes. The Cog bridge, reliably existing since 1346 (Zarębska, 1998, p. 22), opened up new investment opportunities. On the right bank of the river, in the area of today's Granary island, multistorey granaries and warehouses were built, as well as ash, tar and wood storage yards. In 1378, another bridge (Cow bridge), located at the mouth of Ogarna street, leading to the right bank of the Motława river, was built (Cieślak et al., 1978, p. 447). Port functions expanded further towards the eastern bank of the river. As a result, on the right bank, a port district which was inaccessible to residents was created together with a quay stretching along the river, called Long Embankment (Podgórski, 1997, p. 26).

The port of the Castle also expanded its storage and technical areas, shifting some of its activity from the right bank to the area of the Szafarnia (now Ołowianka island). There was a bridge leading to the Szafarnia area, running approximately along with the extension of today's Rycerska street (Zbierski, 1964, p. 142).
In this phase of evolution of the Motława urban blue space (1308-1454; Figure 6b), the ports of the Castle and the Main Town worked in a dual system: the left-bank held city functions, the right-bank port warehouses and granaries (Castle-Szafarnia, Main Town-Granary district). The introduction of multi-storey buildings along the bank created the waterfront of the Granary district and visually closed the interior of the port. The original single-edge layout (the left bank of the Motława) turned into a two-edge structure, where both sides of the port interior were connected by bridges (the castle bridge, $\mathrm{Cog}$ and Cow bridges). Thus, the west bank of the Motława river was lined with a series of piers located at the city's water gates, while the eastern bank had a linear layout. Despite the fact that the port area was inaccessible to its inhabitants, at that time the Motława river became a part of the urban structure of 14th century Gdańsk, constituting its most important water interior.

In 1454, as a result of warfare, the Teutonic castle was completely destroyed and its area remained undeveloped until the middle of the 17th century (Cieślak et al., 1982, p. 414). Gradually, the building density in the area of the agglomeration of the Gdańsk 'cities' was increasing. From 1457, the area began to be treated as a functional whole (Figure 6c), in which the Main Town became the most important centre (Cieślak et al., 1982, p. 7). The port on the Motława river underwent a significant reorganisation, especially within the framework of the existing structure of the Granary district.

From the moment of digging the moat, called New Motława in the years 1454-1456, Granary island became spatially separated. The island was connected to the eastern shore by a bridge at Stągiewna Gate. At the end of the 15th century, almost the entire island was built up with granaries (Cieślak et al., 1982, p. 21; Podgórski, 1997, p. 26). The channel separating Szafarnia from the mainland on its eastern side was also regulated, creating Channel on Keel and Ołowianka island (Cieślak et al., 1982, p. 419). Gradually, the Ołowianka was built over by port warehouses (Cieślak et al., 1982, p. 500).

At that time (1454-1560), the water space on the Motława river took the shape of the letter $\mathrm{H}$ at the intersection of which the Gdańsk crane was located (Figure 6c). Spatially, the port area was divided then into two interiors - two water channels and the most important port's turning basin, resembling by analogy two streets and a square on at their junction. The western edges of the first interior were the city walls, which cut it off from the system of port piers. On the eastern edge of the Motława water space were multi-storey granary buildings located on Granary and Ołowianka islands. The second interior, stretching along New Motława and Channel on Keel, still maintained a single-edge character, and was limited by only one wall of warehouses located on the eastern shore of Ołowianka and Granary islands. Therefore, the $\mathrm{H}$-shaped Motława water space was already quite tightly enclosed within the walls of granaries, warehouses, and city walls. Its interior was, 


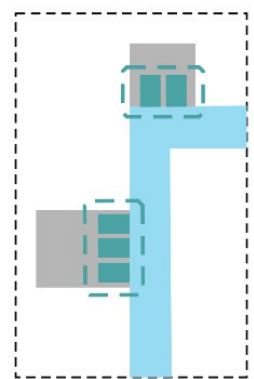

6a 1050-1308

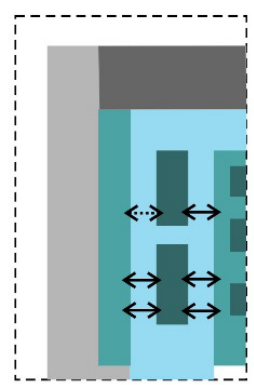

6e 1630-1820

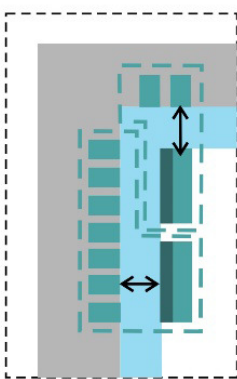

6b 1308-1454

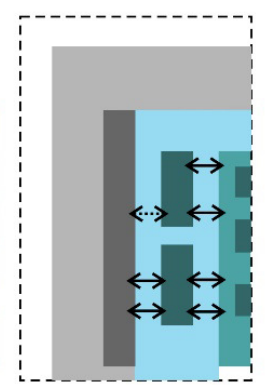

6f 1820-1945

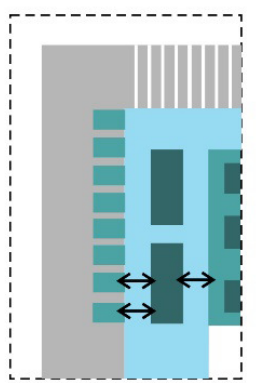

6c 1454-1560

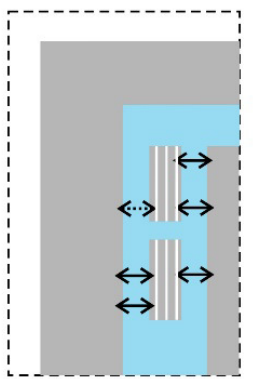

6g 1945-2010

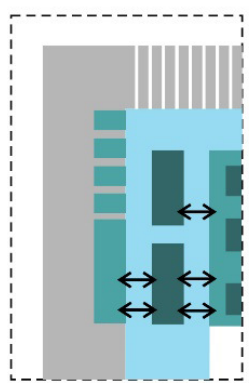

6d 1560-1630

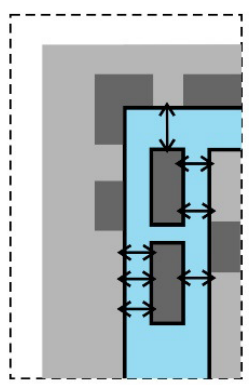

6h 2010 -

Figure 6. Scheme of spatial and functional development of Motława blue space in Gdańsk from 1050 to 2020.

however, not accessible to inhabitants, except port employees. That made the bridge connections even more important for perceiving this water space as a part of the Gdańsk public space system and for the porosity of the Motława urban blue space.

As a result of depth deficits connected with a change in the hydrological system, from around 1560 (Biernat, 1959, p. 218) the port on the Motława became inaccessible for large ships and it served only smaller ships and barges, which carried cargo between the port and the anchorage area next to Vistula river mouth. In 1570, the piers in front of the city water gates between the Green Gate and Holy Spirit street were merged into one long bridge running along the defensive wall of the Main Town (Cieślak et al., 1982, p. 418). Then the bridge was lengthened towards the Old Suburb district (Krośnicka, 2005 , p. 123). In the years 1563-1568, the Green bridge heading to Granary island was rebuilt, and its external spans were enlarged creating vast reloading yards, which Zarębska (1998, p. 47) called the "vestibules of the Long Market." At the turn of the 16th and 17th centuries, bridges connecting Granary and Ołowianka islands with the areas east of New Motława were built. Thanks to the construction of a continuous embankment along the Motława (Figure $6 \mathrm{~d}$ ), the number of mooring places increased. However, more and more cargo was relocated outside of the Motława port. In this phase (1560-1630), the $\mathrm{H}$-shape of the Motława urban blue space was even more enhanced by a new wall of granaries along New Motława. The previous overwater type of land-water edge, dominating on the left bank, was slowly replaced with the vertical structures of wharfs, some of which were publicly accessible. This process, together with the construction of new bridges (Figure 6d), made the
Motława water space more 'permeable' for inhabitants and became, at least visually, a part of the city.

In the years 1630-1640 (Stankiewicz \& Szermer, 1959 , p. 95), fortifications covering the entire urban complex of Gdańsk, including the Old Suburb, former castle, port islands and quite extensive wetlands located east of New Motława were implemented. These last areas were drained and parcelled out (Cieślak et al., 1982, p. 413), and therefore the housing of the so-called Lower Town gradually developed in this area. The medieval walls no longer fulfilled their functions and were 'overgrown' with residential buildings, including on the border between the port and the city (Cieślak et al., 1982, p. 414). A new fortification system allowed for the development of the area of the former Castle and the parcelling of the land adjacent to the Fish Market, which made both areas a part of the Main Town. A comprehensive planning process according to the design from 1648 (Cieślak et al., 1982, p. 414) made the transformation of the area comparable to contemporary waterfront revitalisation projects. Even before 1650, the line of the Main Town's quays was extended to the north, as far as the Fish Market, where short piers for barges were also built (Cieślak et al., 1982, p. 419). Designating the areas of the Lower Town and the former castle for residential purposes led to the surrounding of the port with housing and service buildings (Figure 6e). In order to improve transportation between the right and left banks of the Motława River, at least from 1687, a ferry ran between the crane and Ołowianka island (Litwin, 1998, p. 39).

The siege of the city in 1734 caused the destruction of many buildings in Gdańsk (Cieślak \& Biernat, 1969, p. 181). Gradually, the city was rebuilt. However, in 1772 , at the mouth of the Vistula river to the sea, a new 
port was built, competing with the one on the Motława. The modern district of New Port with its storage areas gradually began to take over the turnover of the old port and weaken its commercial importance. The longestlasting process of integration of urban blue space into the city structure took place in the years 1630-1820 (Figure 6e). Although the $\mathrm{H}$-shaped water area still fulfilled some minor port functions, it became most of all the vivid city centre of Gdańsk (Figure 7).

In 1863, the Motława riverbed was widened next to Ołowianka island (Ciemnołoński et al., 1998, p. 144). In the years 1885-1902, the quays along New Motława and Channel on Keel were rebuilt, and the adjacent basins were deepened. The remaining technically decapitalised port areas were taken over by the functions of municipal infrastructure. In 1852, a railway terminus was built in the southern part of Granary island (Biskup, 1996, p. 107). In 1853, a gas plant was built next to the railway station, and in 1897 a municipal power plant was built on Ołowianka island (Stankiewicz \& Szermer, 1959 , p. 196). In 1884, railroad tracks were led to the north part of Granary island in order to service the port (Biskup, 1996, p. 107). However, the inability to handle large ships limited the possibilities of storing bulk cargo, and the fact that the city densely surrounded the port with buildings and fortifications meant that reloading was gradually eliminated from the old port and transferred to New Port. Around 1840, the port area on the left bank of the Motława was made accessible to inhabitants, and commercial and service functions gradually began to enter its area (Krośnicka, 2005, p. 164). Long Embankment and Stągiewna street have become a full part of the public space of the city. In 1853 , between the Gdańsk crane and St. John street, the embankment was widened (Litwin, 1998, p. 71) and transformed into the city boulevard. The passenger harbour for tourists' steamboats was located there. From 1861, the quay in the vicinity of the former castle became a floating fish market, where goods were sold directly from boats moored to piers (Litwin, 1998, p. 72). Functionally, the area along the Motława river was divided into the eastern port and the western range with services, trade, and recreational activities (Figure 6f). At that time, the area of Granary island, although still fulfilling port functions, became available to the town inhabitants. During the period 1820-1945, the Motława urban blue space was used more and more for recreation, residential, and small trade purposes (Figure 6f). Its porosity and accessibility significantly increased. In this phase, the level of the water space seems to be fully developed.

In 1945, the city centre of Gdańsk and its port were completely devastated. Gradually, as a part of an extensive program, the buildings on the western bank of the Motława river were rebuilt, opting for a historicising approach and preserving the urban layout of medieval Gdańsk. In turn, the eastern shore of New Motława was partially rebuilt using a modernist approach. In this zone, buildings in the form of tall blocks of flats were proposed. In the Lower Town, a large part of the facilities was implemented according to the plan from 1962. The southern part of Granary island was only partially rebuilt. For many years, the ruins of single granaries standing in the open space of the northern headland of the island constituted a specific war memorial in the structure of the city of Gdańsk, being at the same time a focal point of the blue space of the Motława River. The space on

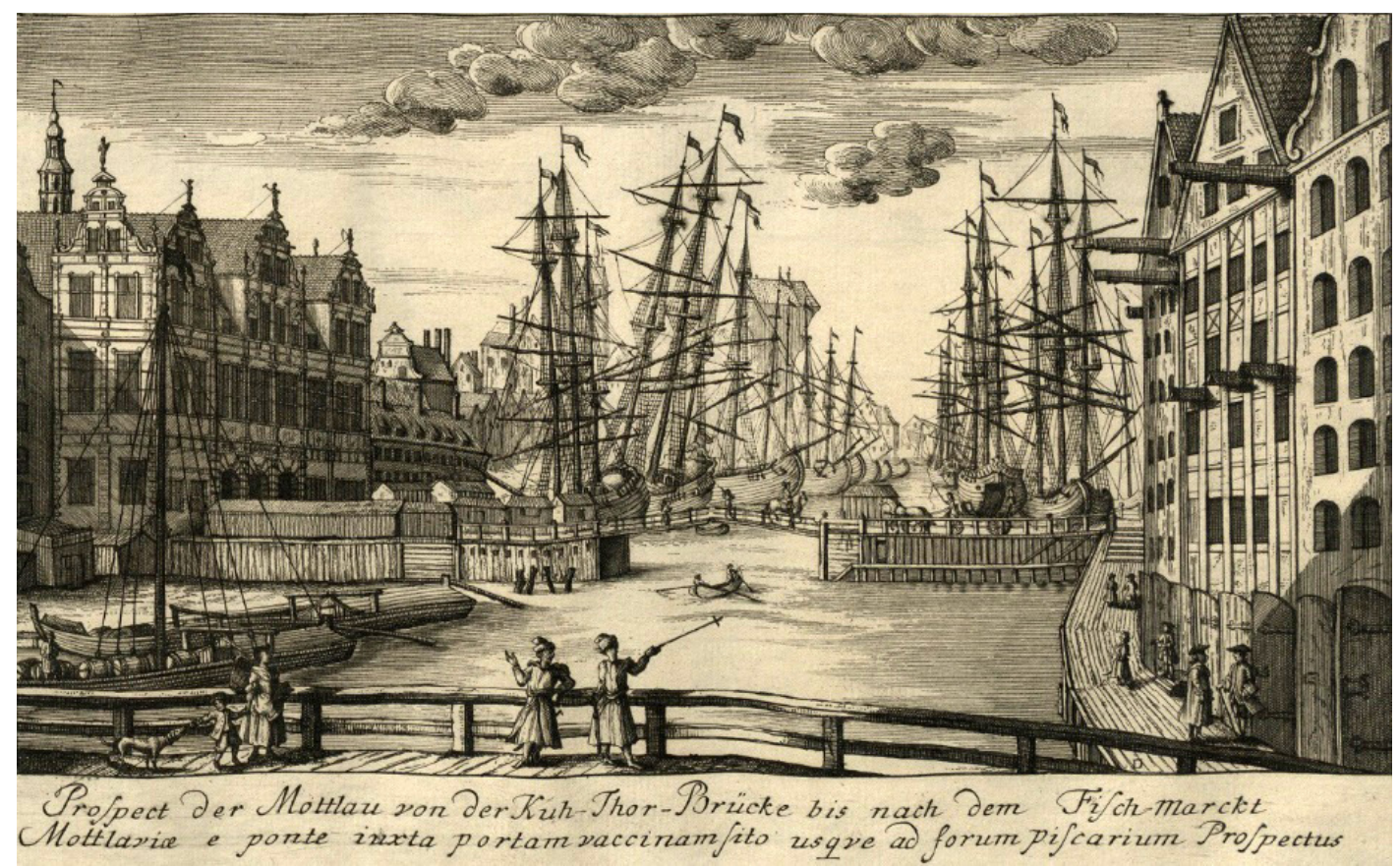

Figure 7. The view of Motława river from the Cow bridge towards the Green bridge, 1761-1765, by Matthäus Deisch. Source: Gedanopedia (n.d.). 
the Motława and New Motława became a large, however not very intensively developed, water plaza, with a strongly marked wall of historicising buildings on the western side and an undefined eastern wall with loose modernist buildings (Figure 6g).

From around 2010, a number of local revitalisation activities were undertaken (Lorens et al., 2018; Szczepański, 2010), and most of them took the form of urban injections within the Motława's blue space. To name a few: Stągiewna street was built-up with historicising tenement houses (the first were built around 1990); residential buildings with service ground floors were erected on the former Brabank in 2016; near the Gdańsk crane, the new facilities of the Central Maritime Museum were built; and several new hotels and apartment quarters were erected along the Motława. Even before 2010, part of the Maritime Museum was moved to old granaries on Ołowianka island (1985), the building of the old power plant on Ołowianka was converted into a philharmonic hall (1997), and a yacht marina was built on the waters of the New Motława (also in 1997). In 2017, the WWII Museum was built, which visually closed the river's interior from the north (Figure 8). In 2017 and 2019, footbridges were built connecting Ołowianka island and Granary island with the western banks of the Motława river to improve its pedestrian accessibility.

The development of Granary island in 2020 can be considered as the completion of the second stage of the reconstruction of Gdańsk after WWII (Figure 8). New buildings, with the intensity of development as well as their heights and shapes, refer to the port warehouses previously existing in this area. Investments implemented in recent years, pedestrian bridges in particular, have significantly activated the water space, increasing pedestrian and water unit movement. The buildings restored the $\mathrm{H}$-shape of the water basins and divided the great water plaza into two parallel 'water streets' (Figure 6h).

The water area of the described urban blue space is currently undergoing the process of marine spatial planning. As this section of the Motława river is legally part of the port of Gdańsk waters, and therefore of Polish marine waters, it is subject to the planning process defined in the Directive 2014/89/EU of the European Parliament and of the Council of 23 July 2014, establishing a framework for maritime spatial planning. Marine spatial planning is a relatively new process, which was first introduced in the late 20th century (Carneiro, 2013; Ehler \& Douvere, 2009; Hassler et al., 2018; Jay, 2012). It is defined as a public process involving the analysis of the existing human activity in the maritime area and its spatial and temporal location, which enables ecological, economic, and social goals set in the political process to be achieved (Ehler \& Douvere, 2009). Directive 2014/89/EU provides a clear indication of the need to take into account the

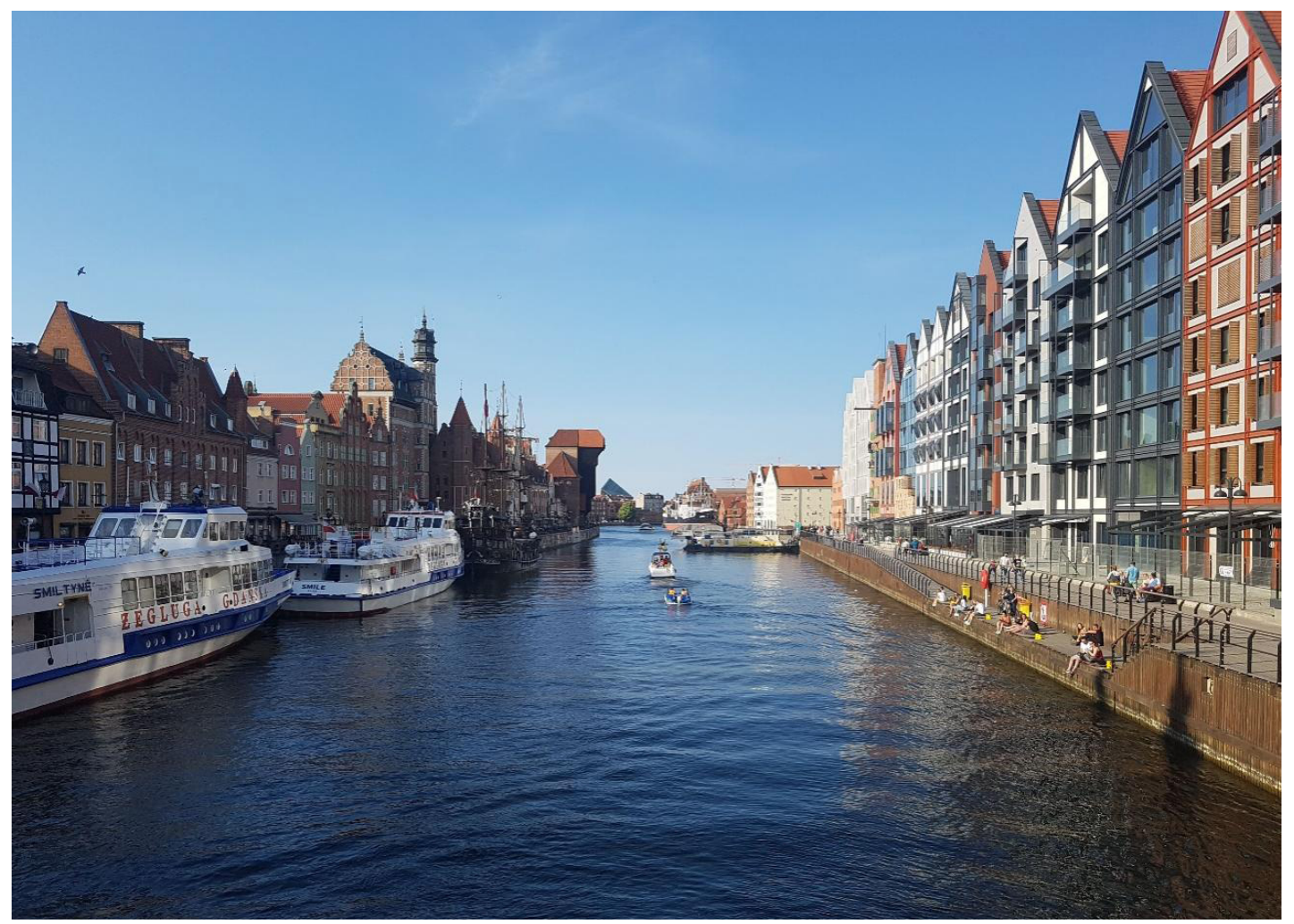

Figure 8. Axis of Motława river heading north, closed visually by the WWII Museum. On the left, the new residential district on Granary island and the Maritime Museum on Ołowianka island visible in the background. On the right, the Gdańsk crane and tenement houses. 
impact and interrelationships between the water and land, although it does not define the tools of this integration (The European Parliament and The Council of the European Union, 2014). According to the Directive, the spatial plan of port waters of Gdańsk must be elaborated up to the year 2023 (The European Parliament and The Council of the European Union, 2014). At the moment, this plan is being developed by the Polish Maritime Office. However, due to parallel planning competencies of the city authorities and the Maritime Office and the novelty of the procedure, this administrative process remains independent from already existing land spatial plans developed by the city authorities.

\section{Evolution of Motława Urban Blue Space in Terms of Theoretical Considerations}

The research in this case study of Gdańsk has shown the functional life cycle of the Motława river blue space (Figure 9). The function of the area was evolving from the natural space (before the year 1050), through the functions of port and industry (1050-1945), infrastructure and transport (1852-2005), into inhabitant-oriented functions, such as housing, services, and recreation (from 1840). These changes were possible due to the relocation of the main port activities to New Port in Gdańsk, a consequence of technological evolution in maritime transportation (increasing parameters of ships).

During the years 1050-1840, the blue space of the Motława performed mainly port functions, isolated from the area of the city. However, due to the erection of new city fortifications in 1630-1640, the old city wall lost its role and the blue space edge on the left bank of the river became more 'porous,' enabling the flow of people. From around 1840, the left bank was completely overtaken by the city functions and both structures - the port and the city-merged. Thus, paradoxically, again an investment taking place at a distance from the Motława defined its new character.

The port activities were led until 1945 on the right bank of New Motława, and on Granary and Ołowianka islands (Figure 9). However, the port was increasingly replaced by infrastructure facilities and transport connected with servicing the city (e.g., power plant, railway terminus, sewage pumping station).

After the damages caused by WWII, the port functions were not reintroduced to the Motława. The left bank was rebuilt as a vivid, multifunctional city structure. From around 1960, residential functions and offices were built along the right bank of New Motława. Since activating the eastern side of New Motława, as well as Ołowianka island and Stagiewna street, and introducing more services (gastronomy, culture, hotels) and recreation to the area, both sides of the Motława blue space have become a functional unity again. In the last couple of years, together with building the multifunctional complex of Granary island, the Motława blue space is even more intensively used. The last period shows the expansions of city functions onto the water (e.g., bridges, marina).

Table 2 shows the evolution of the water-land edges within the Motława urban blue space. As the case study

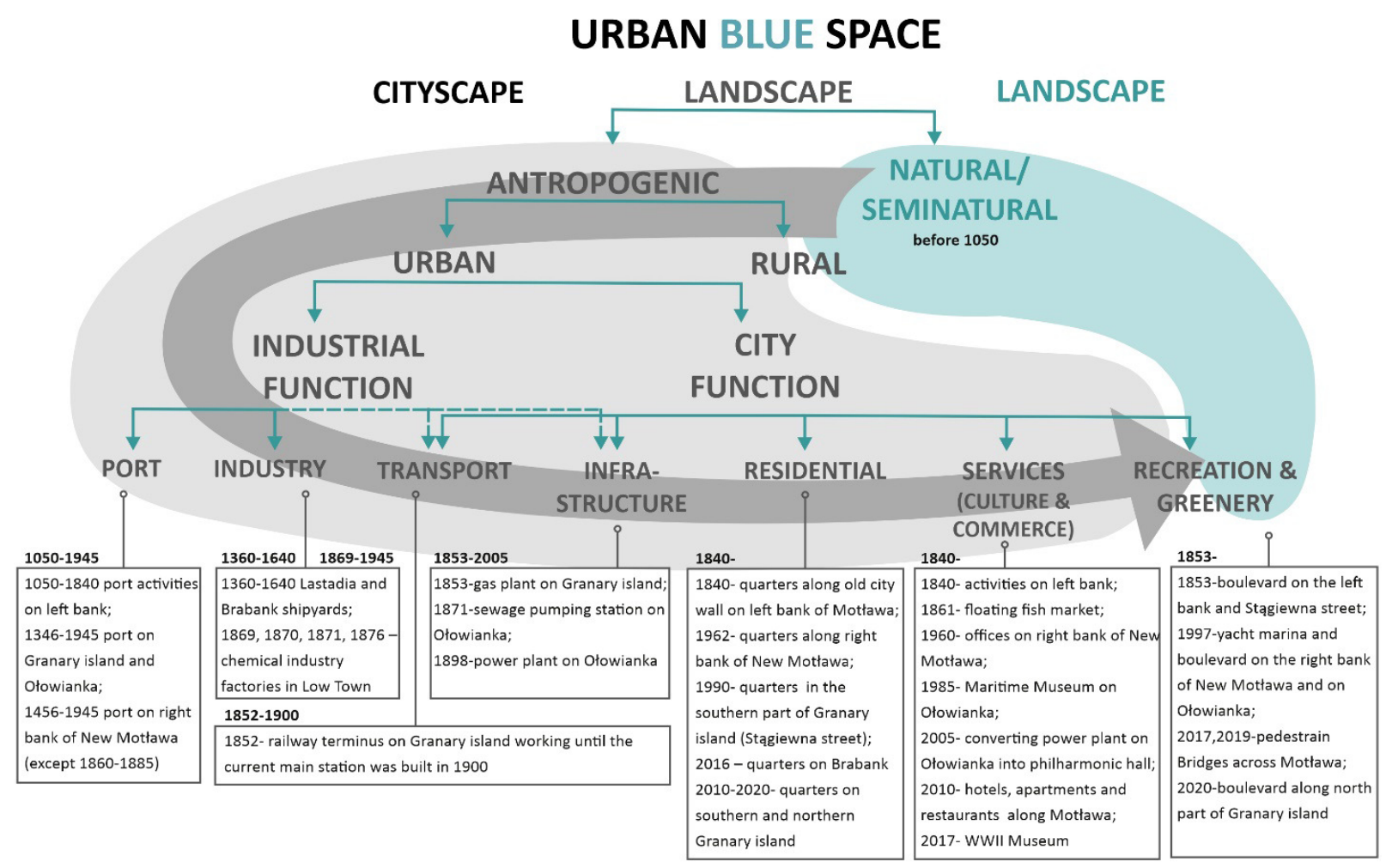

Figure 9. Functional life cycle of the Motława river urban blue space. 
proves (Table 2, column 2), the porosity of the Motława urban blue space has increased in time. This process is connected with the evolution of functions (changing from 'gated' port and industry into functions accessible for inhabitants), as well as changes of the city defence system redefining the location of the urban blue space

Table 2. Evolution of water-land edges and urban blue space edges of the Motława river urban blue space.

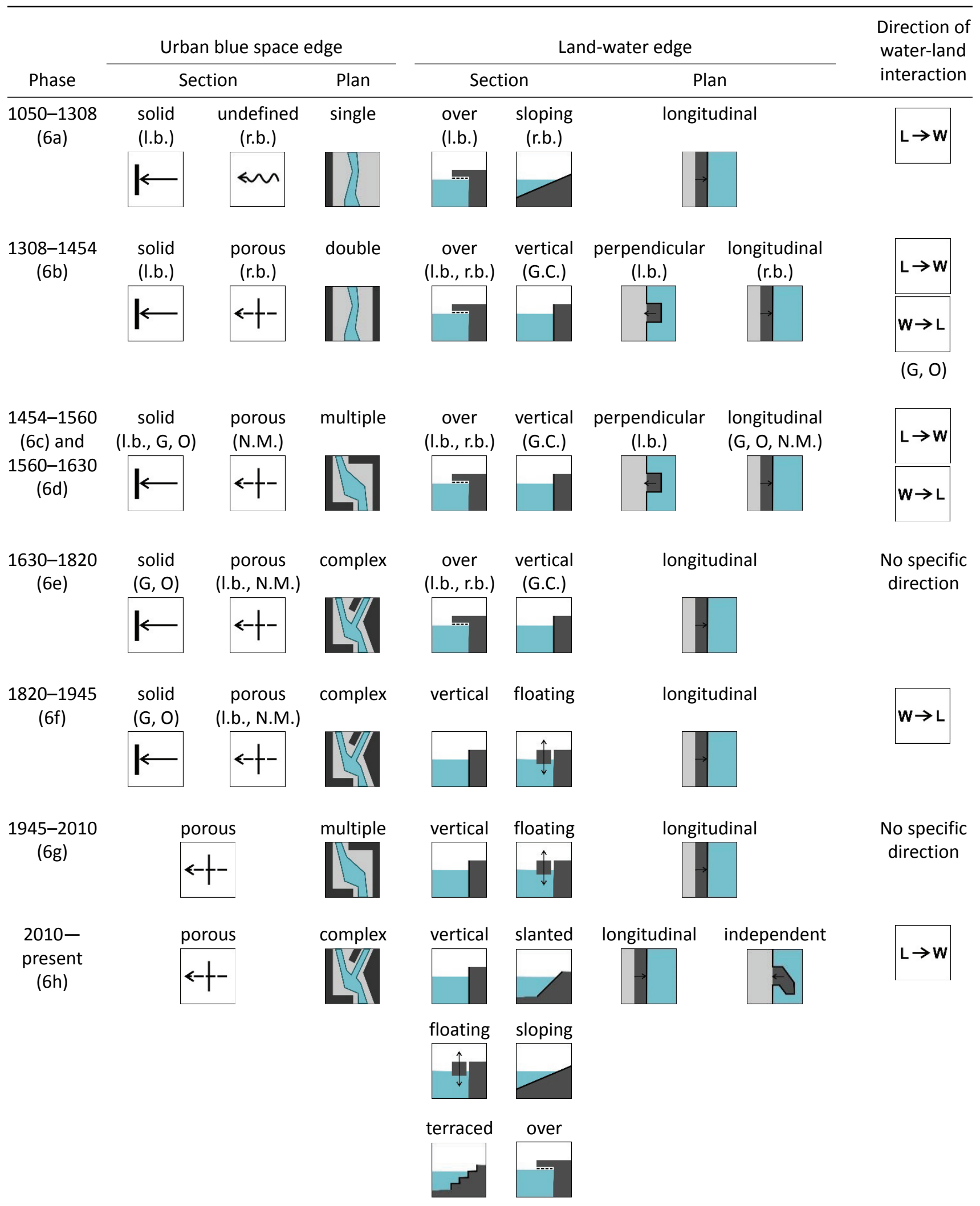

Notes: r.b.-right bank of Motława; I.b.-left bank of Motława; G-Granary island; O-Ołowianka island; N.M.-right bank of New Motława; G.C.-Gdańsk Crane. 
within the structure of the whole city. Therefore, it can be assumed that these two factors - function and water accessibility-define the porosity level of the urban blue space. The level of porosity, in turn, increases the spatial range of the functional connections of the urban blue space.

Considering the evolution of the Motława urban blue space in terms of the structure of its edges (Table 2, column 3), it can be seen that its complexity has increased with time, from a single-edge structure, via double and multiple-edged to a complex network of urban blue spaces. An exception from that rule was the phase 1945-1960 when, due to the damages caused by WWII, the inner part of the blue space was destroyed. That caused the $\mathrm{H}$-shaped blue space network to transform into a simpler but much larger structure of a water plaza. With the construction of a complex on Granary island (2020), this very interesting form of water plaza was again replaced by the historical $\mathrm{H}$-shaped network of water spaces. This change proved how strongly an urban intervention taking place in the inner part of the water blue space might redefine its spatial character and the reception of its space.

Considering the evolution of the plan of the landwater edge (Table 2, column 5), four periods can be delineated: the domination of perpendicular structures between the years 1050 and 1308; the presence of both perpendicular structures (left bank of Motława) and longitudinal structures (right bank) in the years 1308-1630; the domination of oblong structures from the year 1630, as further expansion towards the water was no longer possible due to the limited navigational widths of the river; and finally the introduction of the structures independent from the riverbank, which is a result of the new expansion of recreational functions towards the water.

The evolution of the Motława land-water edges in terms of their section (Table 2, column 4) indicates the increase of their diversity. During the first phases, they usually took the form of wooden overwater piers or shallow vertical structures. From the second phase, stone vertical structures appeared next to the wooden ones (e.g., foundation of the Gdańsk Crane from 1379, and the first concrete wharf from the year 1863 along New Motława). In the last three phases, floating structures appeared (1861-floating fish market, 1985-Sołdek museum ship, 1997-floating jetties of Gdańsk marina). Recently, next to the previously described types, recreational terraced edges appeared along Granary island (Figure 8).

The scheme regarding the development directions of the Motława blue space in time (Table 2, column 6) indicates that both directions (from water to land and vice versa) are possible. Historically, using the water as the area of expansion was considered until the limits of its navigational possibilities (changing in time with the function), while expansion towards land was taking place until the land reserves ended. The postwar periods were usually the turning points in shaping the
Motława blue space, when new paths of development were undertaken.

\section{Conclusions}

The borders and functions of urban blue space dynamically change in time, as shown in the case of Gdańsk. Figure 9 and Table 2, summarising the spatial and functional evolution of the Motława blue space over the almost 1000 years of history of Gdańsk, clearly show that from the long-time perspective, this area should not be considered using the land approach only. The urban blue space is a pulsating space, changing its borders, expanding and contracting along with the economic, demographic, and political events taking place in the city (new investments, population growth or decline, wars), changes in shipping technology (variable size of ships), and defence techniques (city fortifications), where the factor crystallising the urban structure of the area is the water.

The case study shows that the functional borders of urban blue space are flexible due to the life cycle of its functions, and therefore the changing porosity of their edges. The porosity of this space depends on the character of the urban blue space edge as well as on changes in the land-water edge. The water line varies due to changes of water level, dynamic hydrological, as well as investment expansion both towards the water (e.g. piers, jetties, newly built land) and the land (e.g., digging out moats or port channels), thus influencing the waterland spatial relation. The type of edges of urban blue space often depends on their location (e.g., location on the island allowed to get rid of the defence system), but also on the investment activities taking place sometimes away from them-both on land and water. Currently, the water and land areas of urban blue space are administrated by different bodies. The competencies of these bodies, as well as the spatial plans developed by them, stop at the land-water edge instead of covering both elements of the urban blue space. As urban blue space usually consists of both land and water, to manage it effectively and to maintain its functional unity, one common plan should cover both areas.

\section{Acknowledgments}

The authors are grateful to the reviewers and to Professor Carola Hein, the editor of the thematic issue, for in-depth and very insightful reviews and remarks which helped to improve the manuscript significantly.

\section{Conflict of Interests}

The authors declare no conflict of interests.

\section{References}

Biernat, C. (1959). Życie portowe Gdańska w XVII-XVIII wieku [The port life of Gdańsk in the 17th-18th 
centuries]. In G. Labuda (Eds.), Szkice z dziejów Pomorza [Sketches from the history of Pomerania] (pp. 187-270). Książka i Wiedza.

Biskup, M. (1996). Uwarunkowania zmian w układzie przestrzennym portu gdańskiego [Determinants of changes in the spatial arrangement of the port of Gdańsk]. In E. Dejna \& B. Pękała (Eds.), Przyszłość gdańskiego portu. Drogi wodne i szlaki wokót Gdańska [The future of the Gdańsk port. Waterways and routes around Gdańsk] (pp. 11-17). Nadbałtyckie Centrum Kultury.

Brand, D. (2007). Bluespace: A typological matrix for port cities. Urban Design International, 12(2), 69-85.

Breen, A., \& Rigby, D. (1996). Waterfront: Cities reclaim their edge. McGraw Hill.

Breś, J. (2018). Na granicy wody i lądu-pojęcie niebieskiej przestrzeni urbanistycznej [At the edge of water and land-Concept of urban blue space]. Space Economy Society, 14(2), 11-25.

Bruttomesso, R. (1993). Waterfronts: A new frontier for cities on water. International Centre Cities on Water.

Burda, I. M. (2015). Kształtowanie połaczeń Iqdu i wody na terenach poprzemysłowych [Shaping land and water connections in post-industrial areas] [Doctoral dissertation, Technical University of Gdańsk].

Ciemnołoński, J., Czyżak, B., Gruszkowski, W., Romanow, A., Stanielewicz, J., \& Włodarczyk, E. (1998). Historia Gdańska 1815-1920 [History of Gdańsk 1815-1920]. Lex.

Cieślak, E., \& Biernat, C. (1969). Dzieje Gdańska [The history of Gdańsk]. Wydawnictwo Morskie Gdańsk.

Cieślak, E., Górnowicz, H., Łuka, L. J., Zbierski, A., Jasiński, K., \& Biskup, M. (1978). Historia Gdańska do roku 1454 [History of Gdańsk from the year 1454]. Wydawnictwo Morskie Gdańsk.

Cieślak, E., Stankiewicz, J., Samsonowicz, H., Bogucka, M., Nowak, Z., \& Czapliński, W. (1982). Historia Gdańska 1454-1655 [History of Gdańsk 1454-1655]. Wydawnictwo Morskie Gdańsk.

Couling, N., \& Hein, C. (Eds.). (2020). The urbanisation of the sea: From concepts and analysis to design. Nai010.

Couper, A. D. (1983). Atlas of the oceans. Times Books.

Feiler, M. (2007). Floating architecture-PassionFashion-Solution? The new relevance of water in urban and development planning. In L. Nyka (Ed.), Water for urban strategies (pp. 28-35). Bauhaus-Universität Weimar.

Finkl, C. (2004). Coastal classification: Systematic approaches to consider in the development of a comprehensive scheme. Journal of Coastal Research, 20(1), 166-213.

Gedanopedia (n.d.). Most zielony [Green bridge]. https://www.gedanopedia.pl/gdansk/?title=MOST_ ZIELONY

Gledhill, D., \& James, P. (2008). Rethinking urban blue spaces from a landscape perspective: Species, scale and the human element. Salzburger Geographische
Arbeiten, 42, 151-164.

Haeffner, M., Jackson-Smith, D., \& Buchert, M. (2017). Accessing blue spaces: Social and geographic factors structuring familiarity with, use of, and appreciation of urban waterways. Landscape and Urban Planning, 167, 136-146.

Hall, P. (1993). Waterfronts: A new urban frontier. In R. Bruttomesso (Ed.), Waterfronts: A new frontier for cities on water (pp. 12-19). Centro Internazionale Citta D'Acqua.

Hein, C. (2016). Port cities and urban waterfronts: How localized planning ignores water as connector. Wiley Interdisciplinary Reviews: Water, 3(3), 419-438. https://doi.org/10.1002/wat2.1141

Hoyle, B. (1989). The port-city interface: Trends, problems and examples. Geoforum, 20(4), 429-435.

Interaktywny Plan Gdańska. (n.d.). Serwisy mapowe [Map services]. https://mapa.gdansk.gda.pl/ipg/ app/index

Januchta-Szostak, A. (2011). Woda w miejskiej przestrzeni publicznej [Water in urban public space]. Technical University of Poznań Print.

Jerzak, K., Shrayer, M. D., Krośnicka, K. A., Lorens, P., Zaucha, J., \& Pardus, J. (2019). The essence of marine and coastal space: An interdisciplinary perspective. Europa XXI, 36, 15-33. https://doi.org/ 10.7163/Eu21.2019.36.2

Krośnicka, K. (2005). Gdańsk. Ewolucja relacji portmiasto na tle rozwoju technologii żeglugi [Gdańsk. Evolution of the port-city relationship against the backdrop of the development of shipping technology]. Wydawnictwo Akademii Morskiej w Gdyni.

Litwin, J. (1998). Morskie dziedzictwo Gdańska [The maritime heritage of Gdańsk]. Okrętownictwo i Żegluga.

Lorens, P., Grodnicki, R., Osicki, J., Tkaczuk, J., \& Tyślewicz, D. (2018). Przekształcenia frontu wodnego Gdańska [Transformations of the waterfront of Gdańsk]. Studia Komitetu Przestrzennego Zagospodarowania Kraju PAN, 188, 182-212.

Meyer, H. (1999). City and port. International Books.

Meyer, H. (2001). Water in the city as the core of the public domain. In P. Lorens (Ed.), Large scale urban projects (pp. 24-32). Technical University of Gdańsk Print.

Moughtin, C. (2003). Urban design: Street and square. Architectural Press.

Niemann, B., \& Pramel, F. (2017). Renewed urban waterfront: Spatial conditions of a contemporary urban space typology. International Journal of Urban and Civil Engineering, 11(2), 231-238.

Olthuis, K., \& Keuning, D. (2010). Float: Building on water to combat urban congestion and climate change. Frame publisher.

Pido, M. D., \& Chua, T.-E. (1992). A framework for rapid appraisal of coastal environments. In T. E. Chua \& L. Fallon Scura (Eds.), Integrative framework and methods for coastal area management (pp. 144-147). International Center for Living Resources 
Management.

Podgórski, M. (1997). 1000 lat portu gdańskiego [1000 years of the port of Gdańsk]. Oficyna Gdańska.

Prominski, M., Stokman, A., \& Zeller, S. (2012). River. Space. Design. Birkhauser Architecture.

Schwarzer, K., Diesing, M., Larson, M., Niedermeyer, R.-O., Schumacher, W., \& Furmańczyk, K. (2003). Coastline evolution at different time scales: Examples from the Pomeranian Bight, southern Baltic Sea. Marine Geology, 194(1/2), 79-101.

Sherman, D. J., \& Bauer, B. O. (1993). Dynamics of beachdune systems. Progress in Physical Geography, 17(4), 413-447.

Śliwiński, B. (2016). Pomorze Wschodnie w okresie rzq̨ów księcia polskiego Władysława Łokietka w latach 1306-1309 [Eastern Pomerania during the reign of the Polish prince Władysław Łokietek in the years 1306-1309] (2nd ed.). Napoleon.

Sorensen, J. C., \& McCreary, S. T. (1990). Institutional arrangements for managing coastal resources and environments: National park service. US Agency for International Development.

Stankiewicz, J., \& Szermer, W. (1959). Gdańsk. Rozwój urbanistyczny $i$ architektoniczny oraz powstanie zespołu Gdańsk-Sopot-Gdynia [Gdańsk. Urban and architectural development and the establishment of the Gdańsk-Sopot-Gdynia complex]. Arkady.

Szczepański, J. (2010). North-eastern part of Gdansk's historic centre-Revitalisation through culture. In L. Nyka \& J. Szczepański (Eds.), Culture for revitalisation: Revitalisation for culture (pp. 131-138). Centre for Contemporary Art LAZNIA.
Taufen-Wessells, A. (2014). Urban blue space and 'the project of the century': Doing justice on the Seattle waterfront and for local residents. Buildings, 4(4), 764-784.

The European Parliament and The Council of the European Union. (2014). Directive 2014/89/EU of the European Parliament and of the Council of 23 July 2014 establishing a framework for maritime spatial planning.

Vallega, A. (1992). Coastal area management: The need for integrated patterns. GeoJournal, 26, 253. https:// doi.org/10.1007/BF00241232

Vallega, A. (2001). Urban waterfront facing integrated coastal management. Ocean and Coastal Management, 44(5/6), 379-410.

Völker, S., Matros, J., \& Claßen, T. (2016). Determining urban open spaces for health-related appropriations: A qualitative analysis on the significance of blue space. Environmental Earth Sciences, 75(13), 1067.

Yang, D. (2006). Waterfronts: Spatial composition and cultural use [Doctoral dissertation, University College London].

Zarębska, T. (1998). Przebudowa Gdańska w jego Złotym Wieku [Reconstruction of Gdańsk in its Golden Age]. Oficyna Wydawnicza Politechniki Warszawskiej.

Zaucha, J. (2009). Planowanie przestrzenne obszarów morskich: polskie uwarunkowania i plan pilotażowy [Spatial planning of maritime areas: Polish conditions and a pilot plan]. Instytut Morski.

Zbierski, A. (1964). Port gdański na tle miasta w X-XIII w [The port of Gdańsk against the backdrop of the city in the 10th-13th centuries]. GTN.

\section{About the Authors}

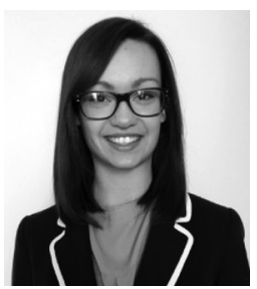

Justyna Breś, MSc. in Architecture and Urban Planning, is an Urban Planner with four years of experience in spatial planning in Poland. She specializes in spatial planning in maritime areas and within the coastal zone. In addition to design practice, she works at Gdańsk University of Technology as a Teaching Assistant in the Department of Urban Design and Regional Planning. Currently, she is working on her doctoral dissertation on the subject of urban blue spaces in Polish port cities.

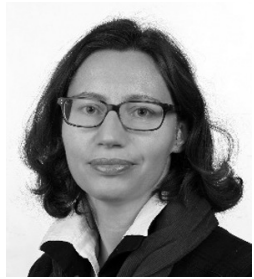

Karolina A. Krośnicka, PhD, D.Sc., educated as an architect and urban planner, is an Associate Professor in the Department of Urban Design and Regional Planning, Faculty of Architecture, at Gdańsk University of Technology. Her current research interests concentrate on port-city spatial relations, planning of ports and post-port areas, Integrated Coastal Zone Management, and the theory of urban dynamics. She is also interested in planning for resilient cities and searching for creative tools allowing urbanized areas to adapt to current challenges. 